\title{
Assessing Olive, Palm Kernel, and Groundnut Oils for their Dermatologically-
}

\section{Active Agents}

\section{Erepamowei Young* and Jackson Godwin**}

*Department of Chemical Sciences, Niger Delta University, Wilberforce Island, P. M. B. 071, Bayelsa State, Nigeria

**Department of Chemical Sciences, Niger Delta University, Wilberforce Island, P. M. B. 071, Bayelsa State, Nigeria

*Corresponding author: E- Mail: erekomu2004@yahoo.co.uk

\begin{abstract}
Skin is the largest organ in the human body and plays important role and hence various expensive creams are formulated to care for it. People place much premium in using expensive creams with little or no knowledge of what less expensive creams (olive, palm kernel, and groundnut oils) can offer in respect of skin care. The aim of this research work was to assess and compare the levels of skin care compounds (Myristic acid, 9-octadecenol, stearic acid, oleic Acid, arachidic acid, Erucic acid) in olive oil, groundnut oil, and palm kernel oil by using gas chromatography - mass spectroscopy. The \%concentrations of the skin care compounds in the samples were: groundnut oil (4-phenylbut-3-ene-1-yne (5.79), Myristic Acid (8.63), Palmitic Acid (22.51), 9-octadecenol (12.76), Stearic Acid (10.89), Oleric Acid (8.34), Arachidic Acid (18.37), Erucic Acid (7.46); palm kernel oil (4phenylbut-3-ene-1-yne (5.83), Myristic Acid (9.21), Palmitic Acid (32.04), 9-octadecenol (21.86), Stearic Acid (18.21), Oleric Acid (9.23), Arachidic Acid (11.24), Erucic Acid (0.96); olive oil (4-phenylbut-3-ene-1-yne (5.79), Myristic Acid (8.63), Palmitic Acid (22.51), 9-octadecenol (12.76), Stearic Acid (10.89), Oleric Acid (8.34), Arachidic Acid (18.37), Erucic Acid (7.46). The levels of skin care compounds follow this order: Palm kernel oil > Groundnut oil = Olive oil, except arachidic acid and erucic acid. 1,2,3-trimethylbensene, $\mathrm{p}^{-}$ mentha-1,3,8-triene, and o-cymene were not found in any of the oils. These ingredients delay ageing, eradicate pimples, rashes and other minute diseases and therefore enhance smoothness of the human skin. Therefore, palm kernel oil is the best oil to be applied on human skin as body cream than groundnut oil and olive oil, since it contains the highest \% composition of the following skin care compounds; myristic acid, palmitic acid, 9octadecenol, stearic acid and 2,3-epoxycarane.
\end{abstract}

Keywords: Skin Care, Palm Kernel, Olive, Groundnut, Oils

\section{INTRODUCTION}

Oil is a smooth, thick liquid that is made from plants and animals with a pleasant smell that can be rubbed on human skin as body cream, used for frying foods and many other important purposes. The primary constituents of the oils particularly groundnut oil, olive oil, palm kernel oil are fatty acids, which play a vital role in determining the quality of food, and thus the health of people as pertaining to the production of various skin care products for the eradication of skin diseases [1]. There has been a long variety history in human civilization of the usage of natural 
ingredients; such as herbs, roots, essential oils, and flowers for skin care [2].

Nowadays, the most common examples of natural skin care ingredients include; palm kernel oil, sesame seed oil, tea tree oil, and many more ([3], [4], [5])

The botanical ingredients influence the biological functions of the skin, providing the nutrients necessary for a healthy skin ([6], [7]). Generally, botanical products are a rich source of vitamins, essential oils, and other bioactive molecules. The use of herbal medicines by communities of African decent is estimated to be $75 \%$ by the World Health Organization ([8], [9]). Skin is the largest organ in the body which protects the internal environment from the external one and adds to beauty too. Beauty is a quality that gives pleasure to the senses, which is desired by many humans.

In general terms, skin disease account for approximately $34 \%$ of the diseases encountered worldwide [10].They affect people of all ages and constitute a major concern for medical consultation. Skin diseases currently exist as a major health burden in both developed and underdeveloped countries [5]. However, mortality rate for skin disease is relatively low, often persistent and are difficult to treat [11].

There are many different ways to protect our skin. The usage of natural ingredients for skincare is very popular today [2].

Medicinal plants have been found to play a major role in the treatment of various skin disorders and these species have been used in many countries around the world where they contribute significantly towards the health care for skin [12].

Moreover, the extensive use of medicinal plants to treat dermatological conditions in traditional system of whole South Africa has already been reported [13].
The search for natural remedies for skin care is ongoing worldwide. A review by [12] focused on the importance of seed oils from six species used in the preparation of cosmetics, also mentioned the traditional and other medicinal usage of seed oils.

Angerosa [14] summarized very systematically the medicinal and cosmetic relevance of the Aloe ferox; a fully explored plant of South Africa which is used in cosmetic herbal formulations.

A published work [15], provided a list of African cosmetic species and their usage. Reports by other researchers such as [16], [17] focused on the significance of Indian herbs and spices used in maintaining and enhancing human beauty as well as these herbs in cosmetics.

Baccouri [18] and [19] reviewed common types of plants used for skin care and concluded that the oxidative stress is one of the major mechanisms for skin aging and dermatological conditions.

The aim of this research work was to assess and compare the levels of skin care compounds (Myristic acid, 9-octadecenol, stearic acid, oleic Acid, arachidic acid, and Erucic acid) in olive oil, groundnut oil, and palm kernel oil. Hence, the objective of this research work was to determine the \% composition of organic compounds contained in groundnut oil, olive oil, and palm kernel oil using Gas chromatography/Mass spectrometry technique.

\section{METHODS AND MATERIAL}

Groundnut oil, palm kernel oil and olive oil were purchased from Amassoma local market situated at Southern Ijaw Local Government Area in Bayelsa State, Nigeria on the $23^{\text {rd }}$ of March, 2018, Chloroform, gas chromatography-mass spectroscopy. 
The 3 samples (groundnut oil, palm kernel oil and olive oil) were analyzed with the same procedure via the use of GC/MS.

\section{RESULTS AND DISCUSSION}

GC-MS analytical results are presented in this section. Figures 1, 2, and 3 respectively show the chromatograms of groundnut oil, palm kernel oil, olive oil. The \%concentrations of organic compounds are shown in Table 1. The \%concentrations of the skin care compounds in the samples were: groundnut oil (4-phenylbut-3-ene-1-yne (5.79), Myristic Acid (8.63), Palmitic Acid (22.51), 9-octadecenol (12.76), Stearic Acid (10.89), Oleric Acid (8.34), Arachidic Acid (18.37), Erucic Acid (7.46); palm kernel oil (4phenylbut-3-ene-1-yne (5.83), Myristic Acid (9.21), Palmitic Acid (32.04), 9-octadecenol (21.86), Stearic Acid (18.21), Oleric Acid (9.23), Arachidic Acid (11.24), Erucic Acid (0.96); olive oil (4-phenylbut-3ene-1-yne (5.79), Myristic Acid (8.63), Palmitic Acid (22.51), 9-octadecenol (12.76), Stearic Acid (10.89), Oleric Acid (8.34), Arachidic Acid (18.37), Erucic Acid (7.46).

The \%composition of 4-phenylbut-3-ene-1-yne, Myristic Acid, Palmitic Acid, 9-octadecenol, Stearic Acid, and Oleric Acid in palm kernel oil were higher than the levels in groundnut and olive oils. However, 2,3-epoxycarane and O-ethyl toluene were not detected in olive oil and 1,2,3-trimethylbensene, $\mathrm{p}^{-}$ mentha-1,3,8-triene, and o-cymene were not detected in palm kernel oil and olive oil. These organic compounds have been known to be skin care agents (Table 2).

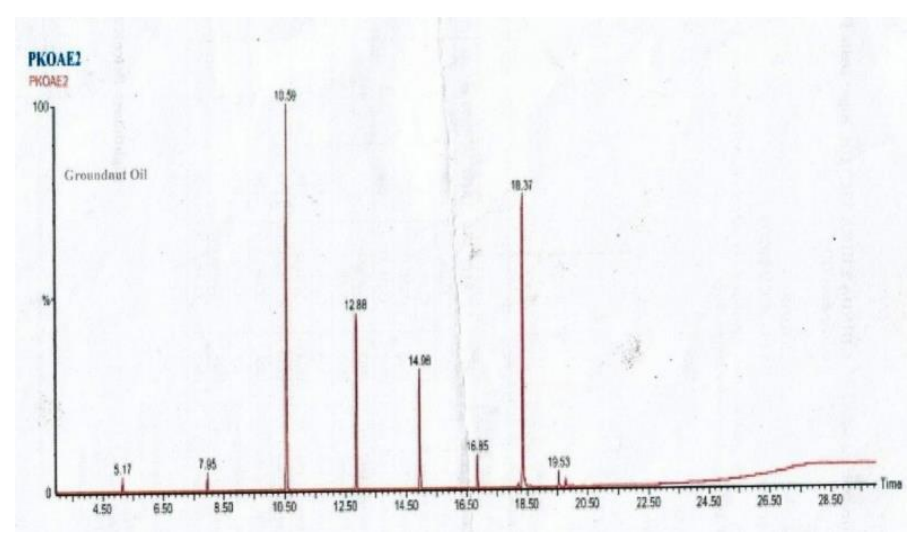

Fig. 1: Chromatogram of Groundnut oil.

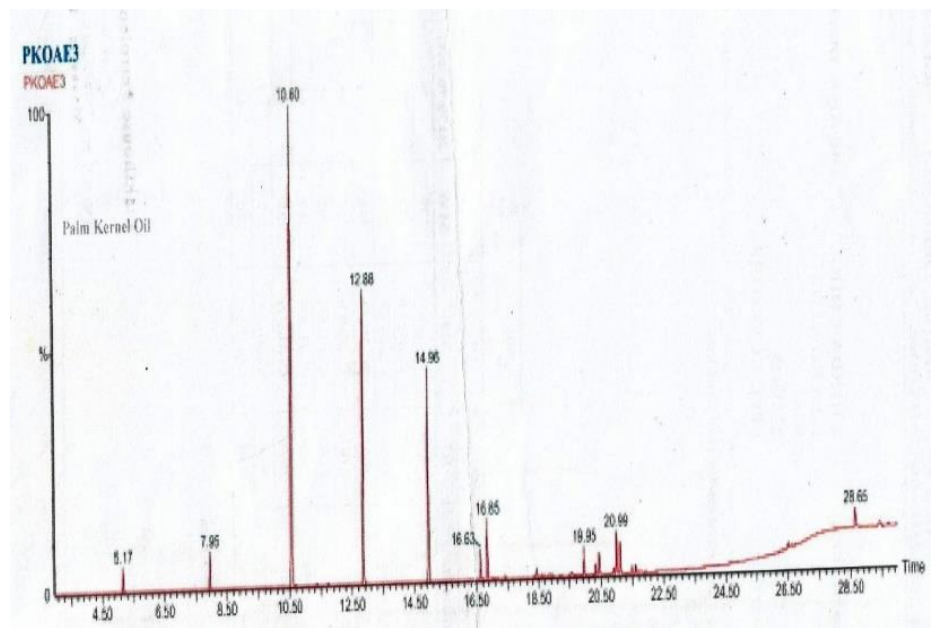

Fig. 2: Chromatogram of Palm Kernel Oil.

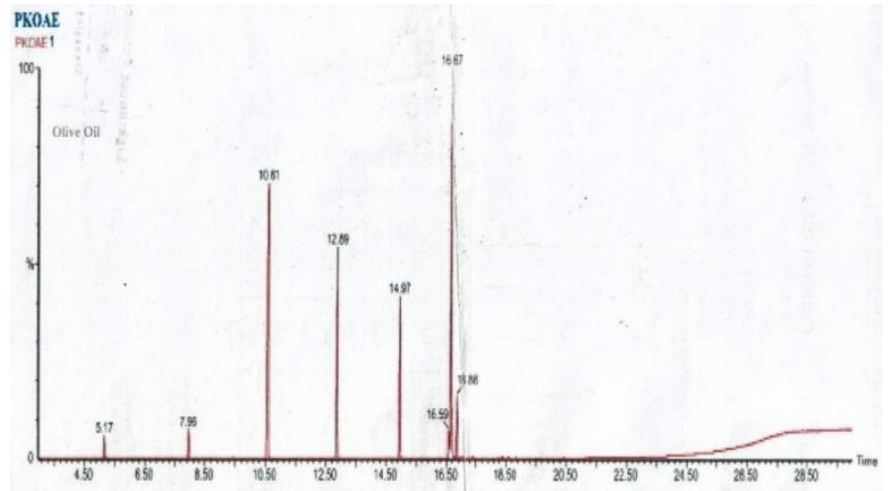

Fig. 3: Chromatogram of Olive oil 
Table 1. Organic compounds in the oil samples

\begin{tabular}{|l|l|l|l|l|}
\hline \multicolumn{1}{|c|}{ S/N } & & \multicolumn{3}{|c|}{ \% Composition } \\
\hline & Components & Groundnut oil & Palm kernel oil & Olive oil \\
\hline 1. & 4-phenylbut-3-ene-1-yne & 5.79 & 5.83 & 5.79 \\
\hline 2. & Myristic acid & 8.63 & 9.21 & 8.63 \\
\hline 3. & Palmitic acid & 22.51 & 32.04 & 22.51 \\
\hline 4. & 9-octadecenol & 12.76 & 21.86 & 12.76 \\
\hline 5. & Stearic acid & 10.89 & 18.21 & 10.89 \\
\hline 6. & Oleric acid & 8.34 & 9.23 & 8.34 \\
\hline 7. & Arachidic acid & 18.37 & 11.24 & 18.37 \\
\hline 8. & Erucic acid & 7.46 & 0.96 & 7.46 \\
\hline 9. & 2,3 -epoxycarane & 0.84 & 5.11 & \\
\hline 10. & O-ethyl toluene & 0.24 & 4.23 & \\
\hline 11. & $1,2,3$-trimethylbensene & 0.11 & & \\
\hline 12. & & & & \\
\hline 13. & p-mentha-1,3,8-triene & 0.14 & & \\
\hline
\end{tabular}

Table 2. Dermatological role of analytes

\begin{tabular}{|c|l|l|l|}
\hline S/N & Organic compounds & Benefits on human skin & References \\
\hline 1 & Myristic acid & $\begin{array}{l}\bullet \\
\text { - It delays ageing. } \\
\text { It is used in the production of shaving products and other } \\
\text { skin care products to eradicate pimples, rashes and other } \\
\text { minute diseases on human skin. }\end{array}$ & {$[20]$} \\
\hline 2 & Palmitic acid & $\begin{array}{l}\text { - It delays ageing. } \\
\text { - It is also used in the production of cosmetics and other } \\
\text { beautifying products that aids in the glittering of the } \\
\text { human skin. }\end{array}$ & \\
\hline 3 & 9-octadecenol & $\begin{array}{l}\text { - It is used in the production of soaps which enhances the } \\
\text { smoothness of the human skin. }\end{array}$ & \\
\hline & & It helps to strengthen the lipid barrier of epidermis. & {$[21]$} \\
\hline
\end{tabular}




\begin{tabular}{|c|c|c|c|}
\hline $\mathrm{S} / \mathrm{N}$ & Organic compounds & Benefits on human skin & References \\
\hline & & $\begin{array}{l}\text { water. } \\
\text { - It normalizes the skin metabolism. }\end{array}$ & \\
\hline 4. & Stearic acid & $\begin{array}{l}\text { - It helps to remove dirt, sweat and excess sebum from the } \\
\text { skin. }\end{array}$ & {$[12],[13]$} \\
\hline 5. & Oleric acid & $\begin{array}{l}\text { - It makes the skin look smooth and properly moistened. } \\
\text { - It activates regeneration of damaged lipid barrier of the } \\
\text { epidermis. } \\
\text { - Heal inflammations and stabilize skin metabolism. } \\
\text { - It catalyzes trans epidermal water loss to improve skin } \\
\text { moistening. }\end{array}$ & {$[12],[13]$} \\
\hline 6. & Arachidic acid & $\begin{array}{l}\text { - It also catalyzes trans epidermal water loss to improve } \\
\text { skin moistening. } \\
\text { - It serves as an important immunomodulatory role to the } \\
\text { skin. } \\
\text { - Heal inflammations and stabilizes skin metabolism. }\end{array}$ & {$[23]$} \\
\hline 7. & Erucic acid & $\begin{array}{l}\text { - It helps to relieve some skin conditions such as pimples. } \\
\text { - It also helps to protect the skin against free radical } \\
\text { damage from ultraviolet light and pollution. } \\
\text { - However, it is also used to ease pain on the human body } \\
\text { system when applied on the skin. }\end{array}$ & {$[12],[13]$} \\
\hline 8. & 2,3-epoxycarane & $\begin{array}{l}\text { - It delays skin ageing. } \\
\text { - Softens the skin. } \\
\text { - Catalyzes metabolic changes that can improve skin } \\
\text { nutrition metabolism. }\end{array}$ & {$[24]$} \\
\hline 9. & o-cymene & $\begin{array}{l}\text { It helps to protect the human skin against most bacteria and } \\
\text { fungi infections. }\end{array}$ & {$[25]$} \\
\hline
\end{tabular}

\section{IV.CONCLUSION}

Myristic acid, palmitic acid, 9-0ctadecenol, stearic acid, oleic acid, arachidic acid, 2,3-epoxycarane are important ingredients of shaving products, cosmetics, soaps, skin care and beautifying products. These ingredients delay ageing, eradicate pimples, rashes and other minute diseases and therefore enhance smoothness of the human skin. Therefore, palm kernel oil is the best oil to be applied on human skin as body cream than groundnut oil and olive oil, since it contains the highest \% composition of the following skin care compounds; myristic acid, palmitic acid, 9-octadecenol, stearic acid and 2,3epoxycarane. 


\section{REFERENCES}

[1]. Singh O., Khanam Z., Misra N., Srivastava M.K. (2011). Chamomile (Matricaria chamomilla): An overview, Pharmacogn Rev., 5(9): 82 - 95.

[2]. Zhang X.H., da Silva J.A., Jia Y.X., Zhao J.T., Ma G.H. (2012). Chemical composition of volatile oils from the pericarps of Indian sandalwood (Santalum album) by different extraction methods, Nat Prod Commun., 7(1): $93-6$.

[3]. Beltran, G., Aguilera, M. P., Del, R.C., Sanchez, S., Martinez, L. (2005). Influence of fruit ripening process on the natural antioxidant content of Hojiblanca virgin olive oils, Food Chemistry, 89 (2): 207 - 215.

[4]. Benicasa, C., De-Nino, A., Lombardo, N., Perri, E., Sindona, G., Tagarelli, A. (2003) Assay of Aroma Active Components of Virgin Olive Oils from Southern Italian Regions by SPMEGC/Ion Trap Mass Spectrometry, Journal of Agricultural and Food Chemistry, 51 (3): 733 741.

[5]. Misra B.B., Dey S. (2012). Differential extraction and GC-MS based quantification of Sesquiterpenoids from immature heartwood of East Indian sandalwood tree, Journal of Natural Sciences Research, 2(6): 29 - 33.

[6]. Bentivenga, G., Dáuria, M., de Bona, A., Mauriello, G (2002). On the Flavor of Virgin Oil. La RivistaItalalianadelle Sostanze Grasse, LXXIX: 101 - 105.

[7]. Bortolomeazzi, R., Berno, P., Pizzale, L., Conte, L. (2001). Sesquiterpene, Alkene, and Alkane Hydrocarbons in Virgin Olive Oils of Different Varieties and Geographical Origins, Journal of Agricultural and Food Chemistry, 49 (7): 3278 3283.

[8]. Boskou, D. (2006). Olive oil composition. In: Olive Oil: Chemistry and Technology. Ed. D.
Boskau, 2nd edition AOCS Press, USA: pp, 41 7.

[9]. Cajka T., Riddellova, K., Klimankova, E., Cerna, M., Pudil, F., Hajslova, J. (2010). Traceability of Olive Oil Based on Volatiles Pattern and Multivariate Analysis, Food Chemistry, 121 (1): $282-289$.

[10]. Allalout, A., Krichène, D., Methenni, K., Taamalli, A., Daoud, D., Zarrouk, M. (2011). Behavior of super-intensive spanish and greek olive cultivars grown in northern Tunisia, Journal of Food Biochemistry, 35 (1): 27 - 43.

[11]. Almirante, P., Clodoveo, M.L., Dugo, G., Leone, A., Tamborrino, A. (2006). Advance technology in virgin olive oil production from traditional and de-stoned pastes: influence of the introduction of aheat exchanger on oil quality. Food Chemistry, 98 (4): 797 - 805.

[12]. Adahchour, M., Beens, J., Vrèuls, R., Batenbur, M. (2004). Comprehensive Two-Dimensional Gas Chromatography of Complex Samples by Using a 'Reversed-Type' Column Combination: Application to Food Analysis, Journal of Chromatography A, 1054 (1 - 2): 47-55.

[13]. Adahchour, M., Brandt, M., Baier, H.U, Vreuls, R.J.J, Batenburg, A.M., Brinkman, U.A. (2005). Comprehensive two-dimensional gas chromatography coupled to a rapid-scanning quadrupole mass spectrometer: principles and applications, Journal of Chromatography A, 1067 (1 - 2): 245-254.

[14]. Angerosa, F. (2002). Influence of volatile compounds on virgin olive oil quality evaluated by analytical approaches and sensor panels. European Journal of Lipid Science Technology, 104 (9 - 10): 639 - 660

[15]. Aparicio, R., Luna, G. (2002). Characterisation of monovarietal virgin olive oils, European Journal of Lipid Science and Technology, 104 (9 - 10): 614 - 627. 
[16]. Aparicio, R. (2000). Authentication. In J. Harwood \& R. Aparicio (Eds.), Handbook of olive oil: analysis and properties, Aspen Publishers, Gaithersburg, MD: 491 - 520.

[17]. Augusto, F., Koziel, J., Pawliszyn, J. (2000). Design and Validation of Portable SPME Devices for Rapid Field Air Sampling and Diffusion-Based Calibration, Anal. Chem., 73 (3): 481 - 486.

[18]. Baccouri, O., Bendini, A., Cerretani, L., Guerfel, M., Baccouri, B., Lercker, G., Zarrouk, M., Miled, D.D.B. (2008). Comparative study on volatile compounds from Tunisian and Sicilian monovarietal virgin olive oils, Food Chemistry, 111 (2): 322 - 328.

[19]. Beens, J., Blomberg, J., Schoenmakers, P. J. (2000). Proper Tuning of Comprehensive

[20]. TwoDimensional Gas Chromatography (GC $\times$ GC) to Optimize the Separation of Complex Oil Fractions, Journal of High Resolution Chromatography, 23 (3): 182 - 188.

[21]. Zieli 'nska, A.; Nowak, I. (2014). Fatty acids in vegetable oils and their importance in cosmetic industry, Chemik, 68: 103-110.

[22]. Tenhaken, R. (2015). Cell wall remodeling under abiotic stress, Front. Plant Sci., 5, (771): 1 $-9$

[23]. Tito, A.; Bimonte, M.; Carola, A.; De Lucia, A.; Barbulova, A.; Tortora, A.; Colucci, G.; Apone, F. (2015). An oil-soluble extract of Rubus idaeus cells enhances hydration and water homeostasis in skin cells, Int. J. Cosmet. Sci., 37: 588 - 594.

[24]. Vertuani, S.; Beghelli, E.; Scalambra, E.; Malisardi, G.; Copetti, S.; Toso, R.D.; Baldisserotto, A.; Manfredini, S. (2011). Activity and Stability Studies of Verbascoside, A Novel Antioxidant, in Dermo-Cosmetic and Pharmaceutical Topical Formulations, Molecules, 16: 7068 -7080.
[25]. Deepak, S.; Shailasree, S.; Kini, R.K.; Muck, A.; Mithöfer, A.; Shetty, S.H. (2010).

[26]. Hydroxyproline-rich Glycoproteins and Plant Defence, J. Phytopathol., 158: 585 - 593.

[27]. Apone, F.; Tito, A.; Carola, A.; Arciello, S.; Tortora, A.; Filippini, L.; Monoli, I.; Cucchiara, M.; Gibertoni, S.; Chrispeels, M.J.; et al. (2010). A mixture of peptides and sugars derived from plant cell walls increases plant defense responses to stress and attenuates ageingassociated molecular changes in cultured skin cells, J. Biotechnol., 145: 367 - 376.

\section{Cite this article as :}

Erepamowei Young, Jackson Godwin, "Assessing Olive, Palm Kernel, and Groundnut Oils for their Dermatologically-Active Agents ", International Journal of Scientific Research in Science and Technology (IJSRST), Online ISSN : 2395-602X, Print ISSN : 2395-6011, Volume 6 Issue 4, pp. 323-329, July-August 2019. Available at doi : https://doi.org/10.32628/IJSRST196453 Journal URL : http://ijsrst.com/IJSRST196453 